\title{
Purchase Power and Consumption Pattern Change of Society (Analysis of 34 Panel Data in Indonesia)
}

\author{
Sri Indriyani S. Dai ${ }^{1} \quad$ Ismet Sulila $^{2}$ \\ 1.Study Program of Economics Development, Faculty of Economics, Gorontalo State University, Indonesia \\ 2.Study Program of Public Administration, Faculty of Economics, Gorontalo State University, Indonesia
}

\begin{abstract}
Purchase power and consumption patterns change are important aspects to formulate government policies in economic development. The research objective is to analyze each the magnitude of macroeconomic variables on real household consumption of 34 provinces in Indonesia. The research method used is correlative quantitative research to explore the relationship of facts proposed and then described systematically, factually and accurately about the facts and phenomena, as well as the variables needed for public consumption. The research results show two finding. First, there is a negative and significant relationship between conversion and consumption of Indonesian. The increase in inflation will be responded by a decrease in consumption of Indonesian in 34 provinces during 2016-2018. Second, Per capita income has a negative and significant impact on consumption of Indonesian in 2016-2018. The research recommendation is to promote Indonesian consumption who moves into slowing phase due to a shifting or consumption patterns change.
\end{abstract}

Keywords: Purchase Power, Consumption Pattern

DOI: $10.7176 / \mathrm{JESD} / 11-2-07$

Publication date: January $31^{\text {st }} 2020$

\section{INTRODUCTION}

Real household consumption expenditure is the largest component of aggregate demand, about $60 \%$ of Gross Domestic Product (GDP), and is therefore an important variable for economic analysis (OECD, 2009). The turbulent global economy has significant effect on Indonesia's economic growth. Viewed from the contribution growth, Indonesia's economic growth is supported by public consumption of more than 55 percent. It means more that than half of Indonesia's economic growth is supported by society consumption.

Lower purchase power of Indonesian in 2017 became a hot issue amid the global economic slowdown. It affected Indonesia's economic growth that increased only 4.76 percent. Weakening of people's purchase power is considered a problem based on assessment and its significant contribution to Indonesian economy as a whole. The purchase power is measured by real consumption of household. Referring to Central Statistics Agency, the household consumption is more important than the combination of Gross Fixed Capital Formation, exports, import and government expenditure. The households do not directly receive contributions from redistribution of tax payments to government in process to generate and distributing income (Hronova and Hindls, 2013).

There are three big reasons that become crucial issues (BPS, 2017). First, its contribution to Indonesia's macro economy is huge. Data showed that over the past year, the real household consumption was far higher than gross fixed capital creation and government consumption. Second, real household consumption is strongly opposed to fluctuations in economic activity. Current consumption affects the future consumption and vice versa, future predictions affect current consumption. Third, household consumption rises in a certain period of time. Society expenditure reflects the income level as financial welfare measurement.

Purchase power is a term, not a theory. Oxford Dictionary of Economics defines purchase power as "The amount of real goods and services each unit of money will buy. Purchasing power is thus the reciprocal of a suitable price index: if prices go up, the purchasing power of money goes down." The hot discussion about weakening purchasing power amid macro data has no clear problem, compilation of unclear coverage can produce macroeconomic data and microeconomic data has no anomaly (Faisal Basri, 2017)

There are four sectors of GDP in last nine years which have a large contribution to Indonesian economy. Among them, the household consumption has contribution more than 55 percent to Indonesian economy. The quarterly growth in household consumption tends to fluctuate. Most critics argue about the weakening of purchase power only because they see a downward trend in real household consumption which forms the largest GDP. Based on quarterly data released by Central Statistics Agency, there is a slowdown in real household consumption. The amount of household consumption is still positive and not weakening. However, the impact of slowing growth in real household consumption could result in a weakening of overall economic growth given the very significant contribution to Indonesia's GDP.

Faisal Basri is LPEM FEB UI researcher. He conveyed through Detik and Republika (August 12, 2017) that the cause of weakening consumption was a shift in people's consumption patterns related to lifestyle. The need for comprehensive research related to slowing growth in real household consumption will be an important consideration to formulate economic policy in future. The issue of purchase power as measured by real household 
consumption approach should identify the affecting factors. Therefore, this research objective is to analyze the magnitude of each macroeconomic variable on household real consumption in 34 provinces in Indonesia.

\section{LITERATURE REVIEW}

\section{A. The Concept of Purchase Power Approached by Real Consumption}

Purchase power is the strength and ability of people to spend their money to get goods and services needed at a certain price and time (BPS, 2017). Above definition shows that people's income can reflect the purchase power. Higher level of income can increase the purchase power to increase demand for items, and vice versa. Public purchase power can be measured by income per capita. However, difficulties in calculating income makes BPS uses consumption as an indicator of income proxy. In addition, real consumption can describe purchase power because the price factor was standardized. The theory of Purchase Power Parity was suggested by Gustav Cassel (1920) that value comparison of one currency with another currency was determined by purchase power of money in each country. The basic theory is the comparison of exchange rates using price levels in each country. There are two versions of purchase power parity theory, absolute and relative version.

Income received by household is used for consumption and savings. Mankiw (2006: 446) said that household consumption decisions affect overall economic behavior in long term and short term. The theory of consumption according to macroeconomic experts is below.

a. Consumption Theory of John Maynard Keynes. One important tool in Keynes's economic theory is the propensity to consume which highlights the relationship between consumption and income. When income increases, consumption also increases, but this increase is not as much as the increase in income (Jhingan, 2014, Keynes in Mankiw (2006).

b. Consumption Theory of Irving Fisher. Consumption theory of Irving Fisher reveals that consumption is based on current and future conditions, where these conditions determine how much income is saved or used for consumption purposes (Mankiw, 2006).

c. Consumption Theory of Milton Friedman. The consumption theory of Milton Friedman offers a permanent income hypothesis to explain consumer behavior (Mankiw, 2006).

\section{B. Economic Growth}

The economic progress of a region shows the success of a development even though it is not the only indicator of development success (Todaro: 2006). There are three types of measures to assess economic growth, namely output growth, output growth per worker, and output growth per capita. Output growth is used to assess the growth of production capacity affected by an increase in labor and capital of the region. Output growth per workforce is often used as the competitiveness changes indicators of region (through productivity growth). Per capita output growth is used as changes indicators in economic welfare (Bhinadi, 2003). Economic growth is the production increase process of goods and services in economic activities of society. (Badrudin, 2017).

\section{Household Consumption}

Consumption definition in economics is broader than consumption definition in daily life which is only considered to be food and drink. Soeharno (2007) defined consumption as the activity to utilize goods or services to meet the necessities of life.

Consumption is absolutely necessary for everyone to survive. Economics call expenses other than savings as consumption. Samuelson (2004) defined household consumption as an expenditure to buy final goods and services that useful to get satisfaction and meet needs. Sukirno (2006) defined that household consumption is the spending value done by households to buy various types of needs in one particular year.

\section{Inflation}

Inflation is a condition where there is a continuous increase in prices for all goods that apply to a particular economy. The characteristics of inflation are below.

a. The money supply is greater than the amount of goods supply, it is shown by Aggregate Demand (AD) is greater than the Aggregate Supply (US).

b. Prices tend to increase continuously.

c. The exchange rate of money has decreased (Detri Karya, 2017)

There are several macroeconomic indicators to determine the inflation rate for a certain period. Three of them are below (Rahardja, 2008).

a. Consumer Price Index (CPI). Consumer Price Index (CPI) is an index number that shows the price level of goods and services that consumers must buy in a certain period.

b. Wholesale Price Index (WPI). WPI is often referred to as the Producer Price Index. WPI shows the level of prices received by producers at various levels of production.

c. Implicit Price Index (GDP Deflator). Economists use the implicit price index (GDP deflator) to get the most 
representative picture of inflation.

\section{RESEARCH METHODS}

\section{Data Types and Sources}

This study uses secondary data in form of pooled data as a combination of time series data for period of 2016 2018 and cross section data for 34 provinces in Indonesia. The data sources are provinces macroeconomic data and Central Statistic Agency. All the data is quantitative data.

\section{Empirical Model}

This is correlative quantitative research type to examine the relationship between the facts of phenomenon under study and then describe systematically, factually and accurately about the facts and phenomena, such as variables affecting the people's consumption. Furthermore, the model was developed by referring to previous empirical study using Society Consumption as dependent variable, while the independent variables are: Inflation, Per capita Income Growth, Labor Productivity, Provincial Minimum Wages, Farmer Exchange Rates (NTP), Gini Ratios, and Percentage of Poor Population. The model to estimate consumption patterns in Indonesia is a panel data model as combination of time series and cross section data. The empirical model of society consumption patterns uses the following models:

$$
\begin{aligned}
& \text { LnCons }_{i, t}=\gamma_{0}+\gamma_{1} \text { INF }_{i, t}+\gamma_{2} \text { YCap }_{i, t}+\gamma_{3} \text { LnUMP }_{i, t}++\gamma_{4} \text { LnProduct }_{i, t}+\gamma_{5} \text { NTP }_{i, t}+ \\
& \gamma_{6} \text { GR }_{i, t}+\gamma_{7} \text { POV }_{i, t}+\varepsilon_{t}
\end{aligned}
$$

LnCons $=$ Society Consumption Logarithm

Inf $=$ Inflation in percent

YCap $=$ Per capita Income Growth Rate

LnUMP = Provincial Minimum Natural Wage Logarithm

LnProduct $=$ Labor Productivity Logarithm

NTP $=$ Farmer Exchange Rate

$\mathrm{GR}=$ Income Inequality measured by Gini Ratio

$\mathrm{POV}=$ Percentage of Poverty

$\mathrm{i}=$ Shows cross section data in this case 34 Provinces in Indonesia

t, t-1 $=$ Current Year and Previous Year

\section{Data analysis technique}

The analysis techniques for panel data are Hausman test and Chow test. There are three approaches to analyze panel data. First is Common Effect, it is same as OLS (Ordinary Regression) method. In essence, intercepts and slopes are fixed between time and individuals. Second is Fixed Effect, the slopes are fixed but intercepts are different between individuals. Third is Random Effect, intercept is considered as a random variable that has an average value. Based on results of Hausman test and Chow test, right model is used to equal people's consumption through the Random Effect Model approach, by weighting it through the coefficient covariance white cross section method.

\section{RESEARCH RESULTS}

Testing the Estimation Model of Panel Data Regression

The selection of estimation models is done by Hausman Test to examine whether the applied models are fixed effect models (different for intercepts and fixed slopes in each region) or random effects (different in intercepts and slopes). Table 1 shows the results.

Table 1. Hausman Test

\begin{tabular}{lrrr}
\hline \hline Test Summary & Chi-Sq. Statistic & Chi-Sq. d.f. & Prob. \\
\hline \hline Cross-section random & 10.887102 & 7 & 0.1436 \\
\hline \hline
\end{tabular}

Source: Analysis Results, 2019

The model selection for panel data regression estimation through the Hausman Test with Eviews (Economics Views) software show that probability value of Hausman test result is significant or the probability is greater than the alpha value $(0.1436>0.05)$. It means so that regression model for prevailing public consumption in 34 provinces in Indonesia is the random effect model. The effect of all independent variables on household consumption is the same or different in each province and also different or changes at each time / year. 


\section{Results of Regression Model Estimation}

The next step is to select the best model was determined using the random effect method. The regression results from random effect method can be seen in following table 2.

Table 2. Regression Estimation Model of Panel Data for Society Consumption

\begin{tabular}{lcl}
\hline \hline \multicolumn{1}{c}{ Variables } & Coeficient & Prob \\
\hline \hline C & 24.648 & 0.0004 \\
Inf & -0.042983 & $0.0312^{* *}$ \\
Ycap & -0.026579 & $0.0242^{* *}$ \\
Ln(UMP) & -0.514809 & 0.2084 \\
Ln(Product) & 0.080121 & 0.7324 \\
GR & -7.006583 & $0.0074 * *$ \\
Pov & -0.082462 & 0.1144 \\
NTP & 0.012507 & 0.2214 \\
\hline \hline R-squared & & 0.763055 \\
Adjusted R-squared & & 0.700729 \\
F-statistic & & 2.616177 \\
Prob(F-statistic) & & 0.016353 \\
Durbin-Watson stat & & 1.755206 \\
\hline \hline
\end{tabular}

Source: Analysis Results, 2019

Table 2 shows that society consumption panel data regression model can be formed as follows: LnCons $=24.648-0.0429$ Inf -0.0265 YCap -0.5148 LnUMP +0.0801 LnProduct $-7.006 \mathrm{GR}-0.082$ Pov + $0.0125 \mathrm{NTP}+\mathrm{E}$

Public consumption without other variables influence is 24.648 percent. Inflation has a negative effects, higher inflation will reduce the public consumption by -0.0429 percent. Growth in per capita income also reduces consumption with a regression coefficient of -0.0265 percent. Provincial minimum wages also reduce the ability of people to consume with a regression coefficient of 0.5148 percent. On other hand, labor productivity can increase public consumption with a regression coefficient of 0.080 percent. Income inequality as measured by Gini ratio decreases public consumption with a regression coefficient of 7.006 percent. Poverty reduces society consumption with a regression coefficient of 0.082 percent while the farmer exchange rate can increase the public consumption with a regression coefficient of 0.0125 percent.

\section{Statistical Testing}

Simultaneous Test (F Test)

Model fit is tested by $\mathrm{F}$ statistic to draw conclusions whether the exogenous variables can describe a linear relationship of endogenous variables. The data analysis results show that $F$ value is 2.6161 with a probability of F-stat of $0.0163<$. If the F-Stat probability value is smaller than alpha $(\alpha=0.05)$, then the exogenous variables simultaneously have a significant effect on endogenous variables.

These results indicate that F-Stat probability value is smaller than alpha $(0.0163<0.05)$. It can be concluded that variables of inflation, per capita income growth, provincial minimum wages, labor productivity, Gini ratio, and poverty and farmer exchange rates simultaneously have a significant effect on public consumption in 34 provinces in Indonesia.

\section{Partial Regression Coefficient Test (t Test)}

The $t$ test was used to examine the partial effect of independent variable on dependent variable. The $t$ test criteria are based on probability value of each regression coefficient. If the probability value is smaller than alpha (Prob. $<\mathrm{A}$ ) where the value of $\alpha$ consists of $0.01,0.05$ and 0.1 , it can be concluded that the variable has a significant effect on dependent variable.

Above estimation results are significant variable. The probability value of inflation variable has a significant effect on public consumption at 0.05 level, per capita income growth has a significant effect on public consumption at 0.05 level, and inequality measured by Gini ratio also has a significant effect on public consumption at 0.01 level.

\section{Coefficient of Determination (Adjusted R2)}

Determination Coefficient Test (Adj.R2) examines the ability of independent variables to explain the dependent variable in 34 provinces in Indonesia. The coefficient of determination (Adj.R2) approaches number 1 shows the ability of model is very good, it means that independent variable provides all the information needed to predict the dependent variable. Based on results of testing using the random effect method, it is found that coefficient of 
determination (Adj.R2) of variables is 0.700729 , it shows that ability of independent variables to explain the dependent variable in 34 provinces in Indonesia is 70.07 percent, while the rest 29.93 percent is influenced by other variables outside the studied variables.

\section{DISCUSSION}

\section{The Effect of Inflation on Society Consumption}

Partially, inflation has a negative and significant effect on consumption. The significant influence of inflation on consumption indicates that consumption is influenced by inflation. The inflation will increase the prices of goods and services. It decreases the real purchase power of people. Lower people's purchase power affects to reduce consumption of goods and services. Conversely, lower inflation (deflation) means a decrease in prices of goods and services. Lower prices of goods and services have caused the people's real purchase power to increase. Increased purchase power of these people will have an impact to increase their consumption of goods and services.

The inflation can change people's income. It can be beneficial or detrimental. In some conditions (low inflation), inflation can encourage economic development. Inflation is a major problem for most economies in world and affects the growth of a country in various ways. Zou et al. (2011) said that inflation is the main factor to cause the social and economic instability. It is also seen as the most observed and tested economic variable, both theoretically and empirically (Faridet at, 2012).

The increase in general price level will decrease the goods or services consumption. In other words, inflation reduces people's purchase power and thus damages economic growth. This conclusion has been supported by Fischer (1993) in Solomon, et. al. (2014) who makes strong conclusions that inflation is not good for long-term economic growth. Barro (1996) in Solomon et. al. (2014) said that stability the price of goods and services is seen as a pillar for economic growth. Inflation does not automatically suppress macroeconomic indicators; it affects the nation's standard of living.

Empirical findings from this study complement economic theory and evidence as well as research of Sulekha, et. al. (2019) that inflation also increases the cost of living and commodity prices and reduces the opportunity to get work for goods. This situation directly affects the household income and their spending capacity. This research is not consistent with Manaseh et. al. (2018) that inflation had positive and significant effect on consumption expenditure. The findings related to short-term and long-term relationship between household consumption expenditure and inflation in Ghana and other studies (Bloom, 2009; Pastor and Veronesi, 2013; Taylor, 2013) that higher inflation increase the price uncertainty, and finally affect on consumption expenditure.

\section{The Effect of Per capita Income Growth on Society Consumption}

Per capita income growth partially has a negative and significant effect on public consumption. An increase in per capita income growth will cause people to reduce their consumption. The income will greatly affect the consumption level of people. These results indicate a weakening of purchase power among Indonesian. Society income or household income has a large influence on consumption level. Higher level of income will increase the consumption level and increases the ability of households to purchase various consumption needs. They may have more consumptive lifestyle, increasing the demands for a very good quality (Rahardja, 2008).

This study results confirms the news in Kompas Daily, September 20, 2017, that a decrease in household consumption occurs because middle-to-upper income groups tend to hold back their spending. It is also caused by relatively low level of demand on household electronic goods such as refrigerators, air conditioners, TVs, sound systems and kitchen equipment. BPS data in first quarter of 2019 showed that food and beverage industry sector grew by 6.77 percent (year on year). Although higher than the fourth quarter of 2018, which was only 2.74 percent, growth in first quarter of this year was the lowest compared to previous years, which touched 8-12 percent. In fact, slowdown in food and beverage sector has been felt at least since the middle of last year. The growth has decreased consecutively since reaching the highest level in fourth quarter of 2017 amounting to 13.77 percent (Republika. 2019).

This study results is not consistent with Aliuddin, et. al. (2014) that there is a positive relationship between income and consumption level. Furthermore, these results are also inconsistent with research of Siregar (2009) which states that national income has a positive and significant effect on amount of public consumption. However, this study supports Rahman et. al. (2019) that income has positive influence on society consumption in Makassar City.

\section{The Effect of Provincial Minimum Wages on Society Consumption.}

The provincial minimum wage based on estimation results shows a negative but not significant effect on consumption. An increase in provincial minimum wage from 2016 to 2018 reduced public consumption by -0.51 percent, assuming other variables were considered constant. This certainly also confirms the results that an increase in per capita income will reduce consumption levels. Wages received by society will most likely tend to be saved and fail to be spent consistent with a shift in spending from non-leisure shopping (food) to leisure shopping 
(entertainment). The Central Statistics Agency (BPS) revealed a shift in consumption patterns of Indonesian. Indonesian prefers to travel (leisure) rather than use their money to shop. BPS Head Kecuk Suhariyanto said, this was evidenced by several indicators of growth in household consumption in third quarter of 2017. Head of BPS Suhariyanto explained, one indicator was the increase in public consumption in hotels and restaurants. In third quarter of 2017, restaurants and hotels grew significantly from 5.01 percent in third quarter of 2016 to 5.52 percent in third quarter of 2017.

Data from Central Statistics Agency (BPS) shows that leisure consumption in second quarter of 2017 grew $6.25 \%$ or faster than the previous quarter which grew 5.5\%. While non-leisure consumption which includes food, clothing, shelter, and other physical objects grew $4.75 \%$ or slowed compared to previous quarter which grew $5 \%$. (BPS, 2017)

\section{The Effect of Labor Productivity on Society Consumption}

Labor productivity at 34 provinces in Indonesia shows a positive but insignificant relationship to people's consumption patterns. An increase in labor productivity can increase the public consumption in general.

Better labor productivity in Indonesia improves the consumption of Indonesian. Labor productivity will affect consumption levels when productivity improves. The structural transformation of Indonesian economy shows that labor productivity, employment and demography contribute positively to economic growth (Khatiwada and Lennon, 2017). Structural transformation is described as the reallocation of resources in three main economic sectors namely agriculture, industry and services (Herrendorf, Rogerson, \& Valentinyi, 2011)

Higher capital and labor inputs in production process are not enough to maintain sustainable growth. Productivity is the main driver of growth after a country reaches the limit usage of their capital and labor. Recognizing the importance of technology in industrial growth, more and more countries and private companies allocate their resources to research and development.

\section{The Effect of Inequality on Society Consumption}

Inequality as measured by Gini ratio from 2016 to 2018 in 34 provinces in Indonesia shows a negative relationship to public consumption. An increase in Gini ratio will be responded to by a decrease in public consumption. The problem of income distribution contains two aspects. The first aspect is how to increase the level of welfare of those who are still below the poverty line, while the second aspect is the overall income distribution in sense of narrowing the difference in income levels between residents or households. This is certainly not good for consumption. Because the income gap will worsen consumption in society. When the income received experiences a significant difference, it will certainly put the brakes on public consumption. And in end it will reduce the consumption of people who are still classified as poor.

\section{The Effect of Poverty on Society Consumption}

Poverty has a negative effect on consumption of Indonesian. The increase of poor people percentage at 34 provinces in Indonesia tends to reduce the consumption level of Indonesian. It is certainly very relevant that, poor people will be very dependent on their income. Without income, society will not shop for consumption. Thus an increase in poor population will reduce the consumption of the poor and affect on lower economic growth.

\section{The The Effect of Farmer Exchange Rates on Society Consumption}

Farmer exchange rates have a positive effect on consumption of Indonesian. An increase in Farmer Exchange Rate (NTP) will increase the consumption of Indonesian. One indicator / measurement that has been used to assess the level of farmers welfare is the Farmers Exchange Rate (NTP) index. Simatupang and Maulana (2008) suggest that unique welfare markers for farm households are practically non-existent, so NTP is the only choice for observers of agricultural development in assessing the level of farmer's welfare. Therefore, NTP is an indicator of relative level of farmer's welfare. NTP is calculated from price ratio between the price received by farmers and price paid by farmers, so NTP is considered a measure of purchase power / exchange ability of farmers against goods purchased by farmers. Higher NTP indicates an increase in real capacity of farmers and indicates an increase in farmers' welfare. It shows relatively more prosperous the farmers life (Silitonga, 1995; Sumodiningrat, 2001; Tambunan, 2003; BPS, 2013, Mashhuri, 2007 in Rachmat, 2013).

The concept of NTP as an indicator of farmers' welfare refers to purchase power of farmers, namely the income ability of farmers to meet the consumption needs. Welfare improvement by increasing income can improve the consumption needs. Therefore, welfare improvement can be achieved through efforts to increase income and or increase household consumption needs. Consistent with increase in purchase power of farmers, it broadly related to two important aspects of policy: first, policy to increase the maximum income of farmers, and second, policy to reduce the costs / expenses of farmers' households. (Rahmat, 2013). 


\section{CONCLUSIONS AND SUGGESTIONS}

Based on above analysis results and discussion, the conclusions can be stated below.

a. Inflation has negative and significant effect of Indonesian's consumption. Higher inflation will be responded by a decrease in consumption of Indonesian in 34 provinces during 2016-2018.

b. Per capita income growth has a negative and significant effect on consumption of Indonesian from 2016-2018.

c. Provincial minimum wages have a negative effect on public consumption. The UMP increase does not necessarily increase public consumption in 2016-2018 time span in 34 provinces in Indonesia.

d. Labor productivity has a positive effect on consumption. Higher labor productivity in 34 provinces in Indonesia can sustain the public consumption in 2016-2018.

e. Gini ratio has a negative and significant effect on consumption. The increase in Gini ratio suppresses the consumption in Indonesia.

f. The percentage of poverty has a negative effect on consumption in Indonesia. An increase poor people will be responded to lower consumption of these people.

g. Farmer exchange rate as a measure of farmers' welfare has a positive effect on society consumption. An increase in NTP will provide an increase in consumption of Indonesian.

Below are important things that need to be considered to encourage the consumption of Indonesian who come

to slower phases due the changes in consumption patterns.

a. Income has a strong relationship with public consumption. Government should to increase economic growth by moving various economic sectors to drive the economy in a better direction that has an impact to improve the welfare of society which is characterized by higher people's income and consumption.

b. The government indeed needs to implement a special strategy to increase the consumption level of middle to lower classes of society. The cash for work program is one of two social assistance programs with a potential to increase consumption of middle to lower classes.

c. The Desired Family Program (PKH) also has the potential to reduce poverty and improve the purchase power of the poor. One indicator is the Central Statistics Agency data which shows the poverty rate fell to 10.12 percent in September 2017. Increasing the number of PKH participants can accelerate poverty reduction while strengthening people's purchase power.

d. Government expenditures both at central and regional levels should accelerated in order to encourage better public consumption.

\section{REFERENCES}

A. Anafo, Solomon, Victor A.Kweku, Felicia Naatu. 2014. The Impact of Inflation on the Standard of Living: A Case Study of Navrongo in the Upper East Region of Ghana. European Journal of Business and Management. Volume 6 Nomor 29 Page 106-115.

Badrudin, Rudi. 2017. Ekonomika Otonomi Daerah. Edisi Kedua. Yogyakarta : UPP STIM YKPN.

Badan Pusat Statistik. 2017. Analisis Isu Terkini. Jakarta : BPS

Badan Pusat Statistik. 2016. Daerah Dalam Angka

Badan Pusat Statistik. 2017. Daerah Dalam Angka

Badan Pusat Statistik. 2018. Daerah Dalam Angka

Ardito Bhinadi, 2003 . Disparitas Pertumbuhan Ekonomi Jawa dan Luar Jawa. Ekonomi Pembangunan. Vol 8. No 1. Juni 2003. Hlm : 39-48

Khan, M. Aliuddin, Israar Ahmad. 2014. An Emperical Study into the Relation of Income and Consumption Using Cross-Sectional Data. ASEE 2014 Zone I Conference.

Taylor, J.B. 2013. Fed Policy is a Drag on the Economy. Wall Street Journal. http://www.wsj.com/ articles. [Last retrieved on 2019 Nov 20].

Bloom, N. (2009), The impact of uncertainty shocks. Econometrica, Volume 77 Nomor 3,Page 623-685.

Pastor, L., Veronesi, P. 2013. Political uncertainty and risk Premia. Journal of Financial Economics, Volume 110 No 3.Page 520-545.

Organisation for Economic Co-Operation and Development (OECD). 2009. National Accounts of OECD Countries 2009. Vol. I. Main Aggregates, OECD Publishing. Available from: http://www.dx.doi. org/10.1787/na_vol_1-2009-enfr. [Last retrieved on 2019 Nov 20].

Siregar, Khairani. 2009. Analisis Determinan Konsumsi Masyarakat di Indonesia [Tesis]. Medan: Universitas Sumatera Utara.

Faisal Basri. (2017, Agustus 12). Diakses pada 2 November 2019 melalui www.faisalbasri. com: https://faisalbasri.com/2017/08/12/sekali-lagi-tentang-daya-beli

Farid, S., Khan, W. A. \& Warriach, I. A. (2012), "Effects of Inflation on Standard of Living: A case study of Multan, Pakistan", Universal Journal of Management and Social Sciences Vol. 2, No.12

Herrendorf, B., Rogerson, R., \& Valentinyi, A. (2011). Growth and structural transformation. Paper prepared for the handbook of economic growth. Retrieved from 
https://www.imf.org/external/np/seminars/eng/2013/SPR/pdf/rrog2.pdf

Raharja, Samsu, Mandala Manurung. 2008. Pengantar Ilmu Ekonomi (Makroekonomi dan Mikroekonomi) Edisi 3. Jakarta : LPFEUI

Gujarati, Damodar, Dawn C.Porter. 2015. Dasar-dasar Ekonometrika. Edisi 5 Buku 1.Jakarta: Salemba Empat. Karya, Detri, Syamsuri Samsudin. 2017. Makro Ekonomi : Pengantar untuk Manajemen. Jakarta: RajaGrafindo

Khatiwada, \& Lennon. (2017). Structural transformation in resource rich countries: a case of Indonesia and Nigeria.ILO Working Paper

Mankiw N, Gregory. 2006. Makro Ekonomi, Terjemahan: Fitria Liza, Imam Nurmawan, Jakarta : Penerbit Erlangga

Manasseh, Charles O, Felicia C. Abada, Jonathan E. Ogbuabor, Josaphat U. J. Onwumere, Chinasa E. Urama, Okoro E. Okoro. 2018. The Effects of Interest and Inflation Rates on Consumption Expenditure: Application of Consumer Spending Model. International Journal of Economics and Financial Issues, Vol. 8 Nomor 4, Page 32-38

Samuelson, Paul A dan William D Nordhaus. 2004. Ilmu Makroekonomi. Jakarta: PT. Media Global Edukasi

Soeharno., 2007. Teori Mikroekonomi. Yogyakarta: Andi Offset

Sukirno, Sadono. 2006. Ekonomi Pembangunan, Jakarta : Kencana.

Rahman, Abdul, Muh. Fikram Alamsyah. 2019. Pengaruh Pendidikan, Pendapatan dan Konsumsi Terhadap Kemiskinan Masyarakat Migran Di Kota Makassar. Jurnal ECCES. Volume 6 Nomor 1 Page :111-129

Rachmat, Muchyidin. 2013. Nilai Tukar Petani : Kosep, Pengukuran dan Relevansinya sebagai Indikator Kesejahteraan Petani. Forum Penelitian Agroekonomi. Volume 31 Nomor 2 Page 111-122

Jhinghan. 2014. Ekonomi Pembangunan dan Perencanaan. Jakarta: PT RajaGrafindo Persada.

Hronova, S., Hindls, R. 2013. Czech Households In The Years Of Crises. Statistics and Economic Journal, Vol. 93 No.4,Page 4-26.

Sulekha, A. ,R.FrancinaPracilaMary,Tharmalingam. 2019. Impact of Inflation of the Household Spending Power. International Journal of Recent Technology and Engineering (IJRTE) Volume-7 Issue-5S. Page 8-11.

Zou, H., Gong, L. \& Zeng, X. (2011), Inflation Aversion. Annals of Economics and Finance, Vol.12 Number 1, page $1-11$

https://ekonomi.kompas.com/read/2017/09/20/060000026/daya-beli-turun-atau-orang-malas-belanja-?page=all diakses pada tanggal 26 November 2019

https://kolom.tempo.co/read/1220241/masalah-penurunan-konsumsi-rumah-tangga/full\&view=ok diakses pada tanggal 26 november 2019.

https://ekonomi.kompas.com/read/2017/11/06/162118326/bps-masyarakat-lebih-senang-travelling-ketimbangbelanja. Diakses pada tanggal 26 November 2019.

https://databoks.katadata.co.id/datapublish/2018/07/24/bappenas-catat-pergeseran-belanja-masyarakat diakses pada tanggal 26 November 2019

http://koran-sindo.com/page/news/2017-08-15/0/0/Tren_Konsumsi_Berubah_Masyarakat_Lebih_Pilih_Rekreasi diakses pada tanggal 26 november 2019. 